\title{
La Conciencia: Dios habla al corazón del hombre*
}

\author{
Monseñor Jean-Louis Bruguès, OP \\ ARCHIVERO Y BIBLIOTECARIO DE LA SANTA IGLESIA ROMANA
}

Son varios los momentos, en nuestras vidas, en los cuales nos gusta prodigar consejos. El primer momento se sitúa al término de la adolescencia, durante el cual desearíamos que todos nuestros descubrimientos fueran reconocidos como evidencias por los que nos rodean. Acuérdense cuando decíamos: "Si estuviese en tu lugar, esto es lo que yo haría", aunque, precisamente, uno nunca puede ponerse en el sitio de otro. Y cuando ya somos viejos, también nos gusta dar consejos; como si fuese esencial para nosotros el tener que transmitir nuestra vivencia personal a los que nos siguen.

Como lo habréis notado, ya no soy tan joven pero, salvo ilusoria ocurrencia mía, tampoco soy aún muy viejo. Son estas razones sufi- cientes como para que me abstenga de daros consejos. Sabiendo que hoy debía tomar la palabra en la prestigiosa Pontificia Universidad Católica de Santiago de Chile, que acaba de ser clasificada primera en la lista de las mejores universidades latinoamericanas, por lo tanto, un lugar donde los estudiantes vienen a aprender, mucho más que un oficio, ante todo el arte de pensar, es mi deseo alentarlos en ese sentido con mis palabras.

En las Jornadas Mundiales de la Juventud de 2011 en Madrid, Benedicto XVI, dirigiéndose a los jóvenes universitarios, les citó Platón: "Busca la verdad mientras eres joven, pues si no lo haces se te escapará de entre las manos" (Parménides, 135d). El Papa añadió: "La juventud es el tiempo privilegiado

\footnotetext{
Este texto corresponde a la conferencia dictada por monseñor Jean-Louis Bruguès, OP, el día 28 de mayo de 2014 en la Facultad de Teología de la Pontificia Universidad Católica de Chile, en el contexto del programa "Ágora UC: Reflexiones en la Universidad".
} 
para la búsqueda y el encuentro con la Verdad". Este breve recuerdo de la escena en El Escorial, nos presenta una convicción que es hoy en día muy escasamente divulgada: la verdad existe y al hombre le es posible buscarla, el hombre puede acercarse a la verdad y acaparar pedacitos de su destello.

Acabo de hablar de una convicción que no es compartida. De hecho, la verdad ha sido descartada de los temas de la filosofía contemporánea. El individualismo se ha apoderado de nuestras sociedades occidentales, haciendo que el individuo se posicione en el centro de su propio universo. Con lo cual, este ya no admite que ninguna autoridad, así sea religiosa, intelectual o política, pueda dictarle las reglas o las normas que rigen su existencia. Sus deseos adquieren fuerza de ley; quiero decir que estos pretenden imponerse en la sociedad como si se tratasen de los derechos mismos. Lo hemos visto con la asistencia médica a la procreación, cuando el deseo del adulto - "un niño si yo lo quiero y cuando yo lo quiero"- fuerza la sociedad a disponer las técnicas médicas del momento al servicio de ese mismo deseo. El individuo ha rebajado las afirmaciones de los demás al rango de simples opiniones y, por lo tanto, son todas eminentemente cuestionables. En este contexto de relativismo generalizado, la verdad ya no tiene su sitio.

El cristianismo afirma lo contrario. Igual que los magos que se dejaron conducir por una estrella en el camino a Belén (Mt 2, 9), el hombre necesita un guía en su peregrinaje sobre la tierra $(\mathrm{He} 11,13)$. Estrella interior, destello del alma, santuario íntimo donde Dios hace oír su voz, la tradición cristiana ha multiplicado las imágenes para caracterizar esta guía tal y como lo hicieron los filósofos de la antigüedad, y ella la llamó conciencia. Ella es la que permite al hombre dirigirse, dándole el conocimiento del bien y del mal. A través de su conciencia, uno es capaz de juzgar el valor moral de sus actos.

Los teólogos cristianos, así como los filósofos griegos, concuerdan en este punto, el hombre puede acceder a la verdad. ¿Cómo y dónde, entonces? En uno de sus textos más hermosos, el Concilio del Vaticano II nos da la respuesta: en lo profundo de su interior. Puesto que el año que viene celebraremos los cincuenta años de la promulgación de la constitución pastoral Gaudium et spes (7 de diciembre 1965), sería bueno que volviésemos a apropiarnos de aquellas palabras:

"El hombre descubre una ley que él no se da a sí mismo, sino 
a la que debe obedecer y cuya voz resuena, cuando es necesario, en los oídos de su corazón, llamándolo siempre a amar y a hacer el bien y a evitar el mal: haz esto, evita aquello. [...] La conciencia es el centro más secreto del hombre, el santuario en el que está solo con Dios y en el que su voz se hace oír. [...] Mediante la fidelidad a la conciencia, los cristianos se sienten unidos a los demás hombres para buscar la verdad y resolver, según la verdad [...]" (\$16).

Es un texto magnífico por su concisión, ya que en pocas palabras nos revela lo esencial de la conciencia, esa voz que habla en el corazón del hombre. Cum-scientia es el término latino que significa no solo que el hombre es capaz de saber, a ciencia cierta, de manera certera, cuál es el bien y la verdad, pero además que su conocimiento le viene del saber mismo de Dios. El escritor francés Albert Camus solía decir: "El hombre de la verdad no envejece".

Existen varias maneras de razonar y discurrir sobre la conciencia humana, empezando por los estudios filosóficos griegos y latinos de la antigüedad, y en particular con el estoicismo. No se reconocerá nunca suficientemente la deuda que tiene toda la moral cristiana con los estoicos. Los pensadores del Pórtico enseñan que las almas des- garradas son infelices. Es necesario, por lo tanto, hallar un principio de armonía gracias al cual una persona puede realizar su unificación interior y alcanzar la concordia con el mundo cósmico. ¿Cómo puede uno conocer al Logos que anima y rige el universo con la Ley eterna? ¿Y siendo ese el precio de la felicidad, cómo puede uno seguir la Ley eterna? Indagaron el principio del conocimiento que reside en lo más profundo de cada hombre, a eso Demócrito y Crisipo le dan el nombre de synéidesis, que los latinos traducirían más tarde por conscientia. Este término permanecerá desconocido del Corán y de las tradiciones musulmanas, donde nada sobrepasa el poder y las decisiones de la comunidad.

Se me ocurrió que hoy en día se acostumbra a apelar con toda banalidad a las sociedades en las que vivimos "civilizaciones de la imagen”. Hablemos pues de imágenes, como la escena de El Escorial que os acabo de presentar. Os propongo que nos detengamos sobre algunas más, con el fin de que juntos abramos un campo de reflexión, el más extenso posible.

\section{El discurso de Westminster HaLL}

La primera de estas imágenes es bastante reciente. El gobierno bri- 
tánico había propuesto que cuatro miembros de la Curia romana pudiesen acompañar al Papa en su viaje de septiembre de 2010 a Gran Bretaña; yo era uno de ellos. No me detendré sobre las críticas y las polémicas que habían precedido este viaje. Sería escasamente verídico hablar de un sencillo éxito: lo que vivimos durante esos cinco días fue un verdadero giro en la Historia. Tendríamos que recorrer con minucioso detalle todos los hechos que llevaron al regreso del catolicismo en la sociedad británica, cuanto más en el corazón de muchos de ellos; mas tan solo una imagen bastará. Fue en la magnífica sala gótica de Westminster Hall. Allí se hallaban reunidos todos los representantes prestigiosos del país, la élite de la vida política y de la sociedad civil; una asamblea numerosa, educada y curiosa, en una palabra, una asamblea propiamente inglesa. Anunciado por trompetas de plata, que de costumbre suenan solo para la Reina, avanzó, no sin cierta timidez, un hombre mayor vestido de blanco y de rojo (colores que son, como bien lo sabéis, los de la Resurrección). Con una voz baja y por momentos fatigada, pronunció un discurso que dejará su huella en la memoria de todos aquellos que estaban presentes, a tal punto que le hicieron una standing ovation prolongada con una inesperada afabilidad.

¿De qué había hablado el Papa? Después de expresar cuánto suscitaba el Parlamento británico la admiración de todos aquellos que, como los católicos, estaban apegados a la búsqueda del bien común, a la vida democrática y al respeto de las libertades personales, explicó que en este comienzo del siglo XXI, la cuestión fundamental era una cuestión eterna, una que se han planteado todas las generaciones: ¿'Sobre qué se erigen las leyes? ¿Con qué derecho y en nombre de qué pueden los gobiernos imponer restricciones a los ciudadanos? ¿ $\mathrm{Si}$ todo fenómeno político halla su origen en una cuestión moral, in fine, cuáles son los fundamentos éticos del discurso civil? Si, y tal como lo pretenden las "éticas de procedimiento", la ley reposa sobre un simple consenso social, queda pues expuesta a una gran fragilidad, ya que las opiniones, como bien lo sabemos, son muy vulnerables a las modas y a las emociones pasajeras. La verdad del bien común existe. ¿Cómo podemos conocer esta verdad? ¿Cómo podemos alcanzarla?

El Papa nos recuerda, al igual que los teólogos más clásicos y tradicionales que "las normas objetivas para una acción justa de gobierno son accesibles a la razón, 
prescindiendo del contenido de la Revelación”. En ese sentido, no hay una política cristiana, una que brote directamente de las Santas Escrituras, sin mediación alguna de la razón. No obstante, la razón sola, librada a sí misma, está expuesta a riesgos y distorsiones. El siglo que acaba de cerrarse dejará tras de sí el recuerdo de un siglo de hierro, en la medida en que la razón, manipulada por la ideología, justificó los peores totalitarismos, los genocidios y las guerras más sangrientas de todos los tiempos. Es aquí donde la religión está llamada a desempeñar su indispensable función social. Sin lugar a duda, también ella puede extraviarse en las desviaciones del sectarismo y del fundamentalismo; sin embargo, desarrolla una función "purificante y constructiva" para con la razón. La religión recuerda incansablemente a su gemela, la política, de donde proviene el bien y lo que ello conlleva. Fe y razón, racionalidad secular y creencia religiosa, ambas tienen sed y necesidad la una de la otra: este diálogo permite acceder a la verdad del bien común. En un plano más general, de este diálogo depende el porvenir de nuestra civilización.

Por esta razón, es preciso reaccionar contra la marginalización de la religión en la vida social y contra el escamoteo de los sím- bolos religiosos. No, la religión no pertenece solamente a la esfera privada.

En su exhortación apostólica Evangelii Gaudium, en la cual se puede apreciar el programa del pontificado actual, el papa Francisco se ha referido insistentemente a este punto: "El proceso de secularización tiende a reducir la fe y la Iglesia al ámbito de lo privado y de lo íntimo. Además, al negar toda trascendencia, ha producido una creciente deformación ética, un debilitamiento del sentido del pecado personal y social y un progresivo aumento del relativismo, que ocasionan una desorientación generalizada [...]" (\$64).

Desde sus orígenes, como lo muestra la predicación de los apóstoles, el cristianismo se expresó en la plaza pública. Y si me permiten, diría que es su sitio natural. $\mathrm{Su}$ mensaje no agradará a todos, por supuesto, pero siempre ha sido así. Hoy en día, las sociedades que rechazan todas las referencias al más allá del siglo (por ello se las llama "secularistas"), y hacen como si el cielo estuviera vacío, proclamando simultáneamente su inclinación a la tolerancia, son forzosamente las que combaten las religiones abiertamente o de manera traicionera, puesto que ellas se refieren a unas leyes superiores que juzgan las le- 
yes de la ciudad. El César no admite ninguna otra autoridad moral más que la suya: es una historia tan vieja como el mundo. Está inscrita en la naturaleza del poder político, la lucha contra cualquier forma de magisterio moral.

Hace seis años salió un libro muy sugestivo, su autor, el filósofo Rémi Brague, recibió el año pasado el prestigioso premio de la Fundación Ratzinger/Benedicto XVI, considerado con una cierta exageración como el "Nobel de la teología”, en el cual mostraba que una sociedad secularizada no ofrecía plaza alguna a la palabra divina.

"La primera condición (en el ejercicio de la democracia) es el rechazo de toda autoridad que pretenda proceder de otro sitio que del interior de dicho espacio (del debate) [...] El poder de la palabra asentado será el de los argumentos, mas no tendrá nada que ver con el origen de aquellos".

En otros términos, el magisterio de la Iglesia no será criticado debido al desagrado que provocan sus declaraciones a las opiniones dominantes, pero justamente porque este pretende expresarse como un magisterio, basando su autoridad en algo extranjero al espacio social. Evidentemente, los "medios” le darán con los golpes más feroces, ya que de hecho se com- portan como si se hubiesen convertido ellos mismos en el nuevo magisterio de las sociedades de opinión. Para estas últimas, cualquier cosa es justificable con el fin de descalificar el magisterio de la Iglesia, percibido como un rival suyo; y eso lo observamos desde hace ya tiempo.

Podemos presentir que el cristianismo se presentará cada vez más como una alternativa a la cultura dominante, como una forma de contracultura, simplemente porque se reclama de una autoridad superior a las voces de la ciudad. Esta autoridad no es nada más que la conciencia moral. Y cada bautizado interroga sin cesar esta conciencia que irradia de la luz divina y se dirige a ella como a una amiga, lucha por ella; hasta puede llegar a morir por ella: he aquí la próxima imagen sobre la cual nos detendremos.

II. LA FIDELIDAD SUPERIOR DE TOMÁs Moro

Al final de su discurso, el Papa fue conducido al centro de la sala, ahí donde Tomás Moro, a quien el Papa había citado repetidas veces, fue condenado a muerte. Se dice que al llegar al pie del cadalso donde debía ser decapitado, Tomás formuló un último pedido; "Le ruego, señor teniente, que me ayu- 
de a subir, porque para bajar, ya sabré valérmelas por mí mismo". Dicho esto, pidió a la gente que lo rodeaba que rezara por él y diera testimonio de su muerte por la Fe y en la Fe de la Iglesia católica. Esta última salida siempre me ha dejado lleno de admiración.

Se nos olvida que el humor inglés a menudo, representa la cara agradable de la fuerza del alma. Y a su vez esta fuerza del alma, en el caso de Tomas Moro, es la señal de un doble compromiso, el que conduce a los hombres a librarse plenamente al servicio público y el que anima a los bautizados a ponerse en camino tras del Señor, e incluso hasta la Cruz. Por lo tanto, existen dos formas de fidelidad: la una es profana, propia a las leyes de la Ciudad, la otra religiosa, implicada por el bautismo cristiano. Es frecuente que estas dos fidelidades se completen y se engrandezcan la una a la otra. La santidad del emperador Enrique de Alemania o del rey Luis de Francia, o también, más cercano a nosotros, la de un Robert Schumann y de un Giorgio La Pira, ilustra esta vocación particular de una santidad que se realiza en el combate político.

Para los cristianos iluminados de aquella época, la entrada en la política se presentaba como evidente. Tomás Moro es un humanis- ta de alto nivel. Conoce a Erasmo, el modelo acabado del intelectual del Renacimiento que le dedicó su Elogio de la locura (Encomium moriae seu laus stultitiae). El antiguo secretario de la Congregación para la educación católica no puede reprimir el gusto de mencionar -lo que era una idea revolucionaria en aquella época- que dio a sus tres hijas una educación igualmente avanzada que a sus hijos. Tomás consigue conciliar las exigencias más contrarias: una feliz vida de familia, una actividad literaria que le asegura una reputación universal y una prestigiosa carrera política. Escribió un gran tratado de filosofía política: Utopía, el cual, cuatro siglos más tarde, sigue siendo un libro de inspiración, una fuente para todos los que sueñan con una política "diferente".

Un famoso cuadro de él, pintado por Holbein, se encuentra en Nueva York: lo he podido observar detenidamente durante mis residencias en esta ciudad. Holbein no tenía ni treinta años cuando se relaciona con este personaje importante, pero lo capta todo, la sonrisa apenas esbozada y burlona a medias, la mirada fija hacia el infinito, y esa serenidad febril que trasluce de su rostro entrañable, aunque esté desprovisto de toda belleza. Tomás se convirtió en el Gran Canciller de Inglaterra 
y desempeñó un papel comparable al de nuestros primeros ministros. Enrique VIII le concedió toda su confianza. Entre los dos se estableció una relación semejante a la de un padre con un hijo, que durará más de veinte años. El Rey está fascinado con la personalidad de su canciller. A menudo va a su encuentro en su despacho; ahí, sentados juntos, "platican tanto sobre la astronomía, sobre la geometría, sobre la teología, como sobre otras disciplinas, y también sobre asuntos temporales. Otras veces, se suben a los tejados para observar juntos las variaciones, los trazados, los movimientos y el rumbo de las estrellas y de los planetas" ${ }^{\text {. Llega- }}$ rá el momento en el cual el hijo condenara a muerte al padre. Esta historia, también, es más vieja que el mundo.

Antes que nada, el problema es político. Poco tiempo después de subir al trono, Enrique desposa a Catalina de Aragón, quien le trae cinco hijos al mundo, pero de los cuales solo una hija sobrevive. Enrique tenía una doble preocupación. Necesitaba tener un hijo para asegurar el futuro de la dinastía que seguía siendo frágil, necesitaba un sucesor enérgico para

Mencionado por el yerno de Moro, William Roper. llevar a cabo la consolidación de la nación inglesa.

Enrique VIII debe, pues, repudiar a su esposa. Espera la declaración de nulidad del Papa; Clemente VII alarga y retrasa los procedimientos. El Rey insiste. Thomas Cromwell, un miembro muy influyente y habilidoso del Parlamento, convence al Rey de seguir el ejemplo de los príncipes alemanes y de separarse de Roma. En 1531, Enrique se proclama jefe supremo de la Iglesia de Inglaterra. Tomás Moro entrega los sellos el 16 de mayo de 1532 . El 12 de abril de 1534 , se le convoca a Lambeth para prestar juramento de fidelidad al Acto de supremacía que restringía la autoridad del Papa y confirmaba el divorcio del Rey. Tomás rechaza dos veces. Solicita al fiscal general, Sir Richard Rich, a quien le había prestado valiosos servicios en varias ocasiones pasadas.

"[...] Suponed -dice Moroque el Parlamento haga una ley exponiendo que Dios no es Dios; ¿diría usted, Master Rich, que Dios no es Dios? -No, señor -responde el fiscal-, yo no lo diría, mas ningún Parlamento osaría promulgar semejante ley. -Pues bien -replica Moro-, [...] el Parlamento no podría tampoco designar al rey como jefe supremo de la Iglesia”. 
Fue condenado por alta traición y murió en el cadalso el 6 de julio de 1535. Tomás Moro siempre fue fiel a su afección al Rey; siempre se mostró seguidor de la política del Rey que quería reunir los pueblos de la isla bajo una sola nación poderosa. Mas un día, estas fidelidades se entrechocaron con una fidelidad que Moro consideraba como superior, y esta es la fidelidad a su conciencia. ¡La palabra conciencia aparece hasta 17 veces en su último escrito bajo forma de testamento! Para un cristiano, la conciencia no es solamente ese espacio íntimo en el cual el hombre delibera consigo mismo antes de tomar una decisión moral. La conciencia es también la elevación del ser, la cual permite al hombre juzgar y sopesar con la mirada misma de Dios. Así lo escribirá otro inglés, tres siglos más tarde, Henry Newman, quien fue beatificado por Benedicto XVI en el transcurso de esa misma visita que os he mencionado. "La conciencia implica una relación entre el alma y algo externo, bien superior a ella; una relación a una perfección que ella no posee, una relación a un tribunal sobre el cual ella no tiene ningún poder" ${ }^{2}$. Esa es la voz misma de Dios, quien entrando en el co-

2 John H. Newman, Sermones universitarios. razón del hombre, le indica el camino del bien y de la verdad. Para Moro, esa misma voz le mostró que la fidelidad a Cristo, la promesa de cada bautismo, implica la fidelidad a Roma, donde se halla la sede del Vicario de Cristo, tal y como lo había escrito unos años antes el mismísimo Enrique VIII.

El antecedente de Tomás Moro nos conduce al corazón de una problemática moderna a pesar de la distancia histórica. Para ser realmente ejercitada, la libertad de conciencia necesita recibir garantías. A la autoridad política le compete inscribir dichas garantías en la ley, tal y como lo recomienda el Catecismo de la Iglesia católica $(\$ 1738)$. En las democracias, las libertades públicas, entre las cuales figura en primera fila la libertad del pensamiento y de expresión, deben ser reconocidas por los textos constitucionales. No obstante, esta garantía puede resultar ser deficiente ${ }^{3}$. Por lo tanto, la libertad de conciencia se apoya principalmente, y ante todo, sobre la protección que la persona le concede. Esta protección se llama la objeción de conciencia. La objeción de

En las sociedades occidentales, actualmente, la tendencia es más bien la restricción de la libertad de religión. Cf. Colectivo bajo la dirección de J. B. D’Onorio, Liberté d'expression, liberté de religion, Paris, Téqui, 2013. 
conciencia se refiere a la negativa de un individuo a obedecer una ley positiva en nombre de unos valores, de unos principios o de una ley más elevada.

Cuanto más se secularizan las sociedades, más numerosas son las situaciones que se presentan en las que se requiere la objeción de conciencia. Hoy en día, la objeción de conciencia concierne más específicamente a los medios hospitalarios; como cuando algunos médicos y enfermeras rehúsan la práctica de abortos o de tomar algún papel en la práctica de la eutanasia activa, y esto, por motivos de conciencia. Hemos de reconocer que a medida que las sociedades se secularizan, más fuerte es su empeño en hacer de la ley positiva la única fuente de ética. Por lo cual, tratan paralelamente de reducir el espacio de tolerancia reservado a la objeción personal. Sobre este punto los cristianos deben prepararse a librar una lucha constante.

III. EL EMPECINAMIENTO DE UNA PEQUEÑA NIÑA

La tercera imagen sobre la cual os propongo detenernos, obliga a atravesar el espacio y el tiempo. De hecho, os convido a irnos hasta la Grecia antigua, en unos tiempos remotos. Se trata de una joven a quien el deber llama y ella desea cumplir con él. A su hermano rebelde lo han matado, y su cuerpo yace en el suelo, despojado de sus vestidos, expuesto a todas las profanaciones. Hay que darle sepultura. El rey Creón, su tío, intenta doblegar a la niña, pues si ella lleva a cabo el proyecto de sus designios, él, siendo el garante del respeto de las leyes de la ciudad, se verá obligado a condenarla a muerte:

Creón: La ley ha sido antes que nada hecha para ti, Antígona, la ley ha sido hecha antes que nada para las hijas de rey Antígona: ¿Qué quiere que haga yo con su política, su necesidad y sus pobres historias? Yo no quiero decir no todavía a todo lo que no me gusta y soy único juez. Y usted con su corona, con sus guardias, con su pompa, solo puede hacerme morir, porque usted ha dicho sí. Jean ANOUIH, Antígona.

Sófocles nos revela el secreto de la obstinación de Antígona: existen leyes que son murmuradas en el corazón. Estas leyes no están escritas, se inscriben directamente en el corazón humano; son de origen divino y son superiores a todas las leyes humanas. La joven del teatro griego nos transmite, pues, un principio determinante para la conducta de nuestras vidas, pero también para cualquier pedagogía humana: vale más morir que traicionar la verdad. Ella lo asegura, 
la verdad existe en lo más profundo de cada uno de nosotros, en lo que más tarde otros llamarán la conciencia. La vida no es el valor supremo y no dicta nuestro deber en toda circunstancia. Cada uno de nosotros descubre en sí mismo una ley eterna, un murmullo que nos habla de la libertad. Es más importante seguirlo que obedecer a las leyes de la ciudad. Sócrates murió por ello, lo acusaron de impío, de trastornar a la juventud, cuando lo que él buscó fue despertar en ella el amor por la sabiduría. Antígona muere por ello, y tantos otros más morirán a lo largo de los siglos, mártires de la fe y disidentes de los regímenes totalitarios de tiempos recientes. Todos habrán preferido exponer sus vidas antes que traicionar el testimonio debido a la verdad. Antígona muere cada vez que un hombre acalla esa voz que susurra lo que es bueno, lo que es recto, lo que es verdadero. Desde Sócrates y Antígona, desde Jesucristo, sabemos que la legitimidad moral no coincide forzosamente con la legalidad social.

John Newman, Tomás Moro, Antígona y hasta el mismo Sócrates: todas estas imágenes sobre las cuales nos hemos detenido, nos revelan una misma cosa: la conciencia humana. Dios nos habla desde nuestro interior. Cuando se trata del bien y del amor, Dios trata de alcanzarnos sin rodeos, directamente. En el santuario de la conciencia, ahí donde se da el encuentro entre la criatura y su Creador, la voz de Dios resuena con una nitidez absoluta: "Busca el bien y quiérelo por lo que es; huye del mal y apártate de él”.

Lo acabamos de ver, existen circunstancias en las cuales la conciencia nos sugiere que lo que es legal no es forzosamente legítimo: la dignidad de la persona al igual que su libertad la incitan a formular una objeción, e incluso, a sublevarse. Max Weber profesaba que cuando ambas se hallaban en oposición, la ética de la convicción (personal) debía siempre inclinarse ante la ética de la responsabilidad (colectiva). El cristianismo cree todo lo contrario: la dignidad del hombre le dicta la orden de seguir su conciencia hasta el final. En marzo de 1990, el Parlamento belga había votado una ley que descriminalizaba el aborto. El rey Balduino I declaró que él no podía, en conciencia, firmar y promulgar dicho texto; prefirió abdicar durante 38 horas para no tener que hacerlo. Algunos le hicieron este reproche: "¿Acaso el Rey está por encima de las leyes?”. La respuesta ya nos fue dada por Tomás Moro: sí, en cada uno de nosotros, y no solo en los reyes, existe un órgano maravilloso que 
nos otorga superioridad sobre las leyes políticas. Es eso lo que hace de nosotros unos seres libres.

¿Por qué escogí hoy de hablaros de la conciencia? Tal y como lo hemos visto, una sociedad secularizada, por definición, excluye de las opciones colectivas cualquier referencia a una transcendencia de carácter religioso o metafísico. Y así, ella puede tratar de erigir en absoluto, cosas que por su naturaleza son relativas: las ideologías, las opiniones individuales, las convenciones sociales, las ideas de moda, sin hablar del funesto "político correcto" venido de los Estados Unidos y que intenta imponer una forma nueva de puritanismo. El César nunca renunció a su omnipotencia. ¿Cómo puede uno denunciar la "dictadura del relativis- mo", o mejor dicho, tomando las palabras del papa Francisco, "una relativa indiferencia relativista, relacionada con el desencanto y la crisis de las ideologías que se provocó como reacción contra todo lo que parezca totalitario" (EG \$61)? ¿Cómo proteger a la persona contra estas innumerables presiones que se emplean silenciosamente para limitar su libertad de pensamiento y su libertad de expresión? Conozco una sola respuesta: a tiempo y a destiempo se ha de repetir a esa persona que precisamente en ella hay algo más grande que la sociedad, un espacio íntimo donde el Creador sugiere a la criatura hecha a su imagen, lo que él desea, lo que él espera de ella. ¡Cum-scientia: el saber del saber mismo de Dios! 